\title{
Crime and justice
}

- The British Crime Survey (BCS) showed that there were 10.7 millions crimes committed against adults living in private households in England and Waes in 2008/09, 8.7 million fewer crimes than in 1995. (Table 9.2)

- According to the BCS in England and Wales in 2008/09, victims of domestic violence were most likely to report being a repeat victim, with 38 per cent of domestic violence victims experiencing this crime more than once in the 12 months prior to interview. (Figure 9.4)

- The number of crimes reported to the police in England and Wales in which a firearm excluding air weapons had been used was 8,208 in 2008/09, a fall of 17 per cent compared with the previous year. (Figure 9.6)

- In 2008, there was a total of $f 609.9$ million worth of plastic card fraud losses on UK issued cards, the highest recorded since 1998, when $\mathrm{f} 135.0$ million worth of fraud losses occurred. Losses of $f 379.7$ million ( 62 per cent) occurred in the UK, compared with f230.1 million (38 per cent) of fraud which occurred abroad. (Figure 9.8)

- Police officers from ethnic minority groups accounted for 4.4 per cent of total police officer strength in England and Wales at 31 March 2009. (Table 9.19)

- In 2008/09, a total of 31,259 complaint cases were made by members of the public against those serving with the police in England and Wales, an increase of 8 per cent on the previous year and the most complaints recorded in a single year since 1990. (Figure 9.21) 
Many people will be affected by crime during the course of their lives, either directly through loss or suffering, or indirectly through, for example, experiencing heightened levels of fear. This can restrict people's behaviour, or mean that they feel they have to take additional security measures in the course of their daily life. Crime and its associated problems are a continuing concern for society and the Government. There are two main sources of statistics on crime levels: household population surveys of people's experiences of crime, and police records of crime (see Measures of crime text box).

\section{Crime levels}

This chapter discusses the incidence and the prevalence of crime (see also Appendix, Part 9: Prevalence rates and incidence rates). The prevalence of crime, or the percentage of people who were victims, is covered in the Offences and

\section{Measures of crime}

There are two main measures of the extent of crime in the UK: surveys of the public, and crime recorded by the police. The British Crime Survey (BCS) interviews adults aged 16 and over who are living in private households in England and Wales. The Scottish Crime and Justice Survey (SCJS) and the Northern Ireland Crime Survey (NICS) interview adults aged 16 and over in Scotland and Northern Ireland respectively. In some ways the BCS, the SCJS and the NICS give a better measure of many types of crime than police-recorded crime statistics. These surveys show the large number of offences that are not reported to the police and also give a more reliable picture of trends, as they are not affected by changes in levels of reporting to the police or by variations in police recording practice (see Appendix, Part 9: Types of offence in England and Wales, in Scotland, and in Northern Ireland).

Recorded crime data cover offences reported to, and recorded by, the police. The National Crime Recording Standard (NCRS), introduced in England and Wales in 2002 and the Scottish Crime Recording Standard (SCRS), introduced in 2004, were implemented with the aim of taking a more victim-centred approach and providing consistency between police forces (see Appendix, Part 9: National Crime Recording Standard).

Police-recorded crime and survey-measured crime have different coverage. Unlike crime data recorded by the police, surveys are generally restricted to crimes against adults living in private households and their property and do not include some types of crime (for example, fraud, murder and victimless crimes such as drug use, where there is not a direct victim).

See also Appendix, Part 9: Availability and comparability of data from constituent countries victims section later in the chapter. The incidence of crime, or the number of crimes experienced, is analysed in this section.

In 2008/09, there were 5.2 million crimes recorded by the police across the UK (Table 9.1), this was a fall of 5 per cent from 5.4 million offences in 2007/08. In England and Wales, recorded crime also fell by 5 per cent between $2007 / 08$ and 2008/09, to reach 4.7 million notifiable offences. Nearly three-quarters (71 per cent) of recorded crimes in England and Wales were property crimes; these include theft and handling stolen goods, burglary, offences involving a vehicle, criminal damage and fraud and forgery. Almost a fifth (19 per cent) of all recorded crime involved violence against the person.

The definition of crime in Northern Ireland is broadly comparable with that in England and Wales. The police in Northern Ireland recorded 110,000 crimes in 2008/09. Theft and handling stolen goods accounted for 24 per cent of all recorded crimes, a lower proportion than in England and Wales or Scotland. In Northern Ireland criminal damage and violence against the person formed higher proportions of recorded crime, at 26 per cent and 27 per cent respectively.

\section{Table 9.1}

\section{Crimes recorded by the police: by type of offence, ${ }^{1}$ 2008/09}

United Kingdom

Percentages

\begin{tabular}{|c|c|c|c|}
\hline & $\begin{array}{l}\text { England } \\
\& \text { Wales }\end{array}$ & Scotland & $\begin{array}{l}\text { Northern } \\
\text { Ireland }\end{array}$ \\
\hline Theft and handling stolen goods & 36 & 34 & 24 \\
\hline Theft from vehicles & 8 & 4 & 3 \\
\hline Theft of vehicles & 3 & 3 & 3 \\
\hline Criminal damage & 20 & 29 & 26 \\
\hline Violence against the person ${ }^{2}$ & 19 & 3 & 27 \\
\hline Burglary & 12 & 7 & 11 \\
\hline Drugs offences & 5 & 11 & 3 \\
\hline Fraud and forgery & 3 & 2 & 3 \\
\hline Robbery & 2 & 1 & 1 \\
\hline Sexual offences & 1 & 1 & 2 \\
\hline Other offences ${ }^{3}$ & 2 & 12 & 3 \\
\hline $\begin{array}{l}\text { All notifiable offences } \\
\qquad(=100 \%) \text { (thousands) }\end{array}$ & 4,702 & 377 & 110 \\
\hline
\end{tabular}

1 See Appendix, Part 9: Types of offences in England and Wales, in Scotland and in Northern Ireland, and Availability and comparability of data from constituent countries.

2 Data for Scotland are serious assaults only. Those for England and Wales and Northern Ireland are all assaults including those that cause no physical injury.

3 Northern Ireland includes 'offences against the state'. Scotland excludes 'offending while on bail'.

Source: Home Office; Scottish Government; Police Service of Northern Ireland 
In Scotland the term 'crime' is reserved for the more serious offences, broadly equivalent to 'indictable' and 'triable-eitherway' offences in England and Wales, while less serious crimes are called 'offences' (see Appendix, Part 9: Types of offences in England and Wales, in Scotland and Northern Ireland). The most common recorded crime in Scotland in 2008/09 was theft and handling stolen goods (34 per cent), followed by criminal damage (29 per cent) and drugs offences (11 per cent).

The British Crime Survey (BCS) estimates of crime are considerably higher than the number of crimes recorded by the police. Many crimes reported to the BCS are not reported to the police, for a variety of reasons. For example, people may consider that the crime was too trivial, or that it was not worthwhile reporting because there was no loss involved. Whether or not a crime had been reported to the police varies by type of offence. Of the comparable crimes covered in both the BCS and police records, (see Appendix, Part 9: Comparable crimes) in 2008/09 theft of a vehicle was the most likely crime captured in the BCS to be reported to the police: 89 per cent of all thefts of vehicles in England and Wales had been reported. Burglaries in which something was stolen had the second highest reporting rate (83 per cent). This is at least in part because both these types of crime need to be reported to the police if the victim wishes to make an insurance claim.

Of the 10.7 million crimes reported to the British Crime Survey (BCS) in England and Wales in 2008/09, almost two-thirds (6.8 million offences) were household crimes (Table 9.2). The

\section{Table 9.2}

\section{British Crime Survey offences ${ }^{1}$}

\begin{tabular}{lrrr} 
England \& Wales & $\begin{array}{r}\text { All household } \\
\text { crime }\end{array}$ & $\begin{array}{r}\text { All personal } \\
\text { crime }\end{array}$ & $\begin{array}{r}\text { All BCS } \\
\text { crime }\end{array}$ \\
\hline 1983 & 7.7 & 4.2 & 11.9 \\
1987 & 9.0 & 4.4 & 13.4 \\
1991 & 10.4 & 4.7 & 15.1 \\
1995 & 12.4 & 6.9 & 19.4 \\
1999 & 9.4 & 5.6 & 15.0 \\
$2003 / 04$ & 7.2 & 4.5 & 11.7 \\
$2007 / 08$ & 6.5 & 3.8 & 10.2 \\
$2008 / 09$ & 6.8 & 3.9 & 10.7 \\
\hline
\end{tabular}

1 Until 2000 respondents were asked to recall their experience of crime in the previous calendar year. From 2001/02 onwards the British Crime Survey (BCS) became a continuous survey and the recall period was changed to the 12 months prior to interview.

Source: British Crime Survey, Home Office remainder, 3.9 million offences, were personal crimes. The total number of crimes estimated by the BCS rose steadily throughout the 1980s and early 1990s and peaked in 1995, at 19.4 million. Estimated crime levels then declined steadily until 2004/05 and have remained broadly stable since.

The Scottish Crime and Justice Survey (SCJS) estimated that around 1.04 million crimes were committed against adults in private households in Scotland in the 12 months prior to interview in 2008/09, 70 per cent of which were property crimes. The remaining crimes were violent crimes of assault and robbery.

Estimates from the Northern Ireland Crime Survey (NICS) estimated that 176,000 crimes were committed against adults living in private households in the 12 months prior to interview in 2008/09. This was a fall of almost 12 per cent compared with the total of 199,000 in 2007/08, and was two-fifths (40 per cent) lower than the peak recorded in 2003/04 (295,000 crimes)

\section{Offences and victims}

According to the 2008/09 British Crime Survey (BCS), around 23 per cent of all adults aged 16 and over in England and Wales had experienced one or more BCS crimes in the 12 months prior to interview. The most common crime experienced was vandalism, with 2.8 million incidents in the 12 months prior to interview (Table 9.3 overleaf). There were 1.5 million incidents of vehicle-related theft (including theft of, or from, motor vehicles, but not bicycles), a fall of two-thirds (66 per cent) since 1995. In 2008/09, vehicle-related thefts accounted for 14 per cent of BCS crime, compared with 23 per cent in 1995

In Northern Ireland in 2008/09, around 13 per cent of households were victims of at least one Northern Ireland Crime Survey (NICS) crime during the 12 months prior to interview, which is the lowest level of victimisation since the survey began in 1994/95. In Scotland in 2008/09, 20 per cent of adults were the victim of at least one Scottish Crime and Justice Survey (SCJS) crime during the 12 months prior to interview.

Being a victim of crime can be traumatic and the impact can vary depending on the type of offence and the circumstances under which it occurs. For example, the impact can be worse when a person is repeatedly victimised. In the BCS, repeat victimisation is defined as being a victim of the same offence, or group of offences, more than once within a 12 month period. According to the BCS in England and Wales in 2008/09, 9 per cent of victims who experienced theft from the person in 
Table 9.3

\section{Incidents of crime: by type of offence ${ }^{1}$}

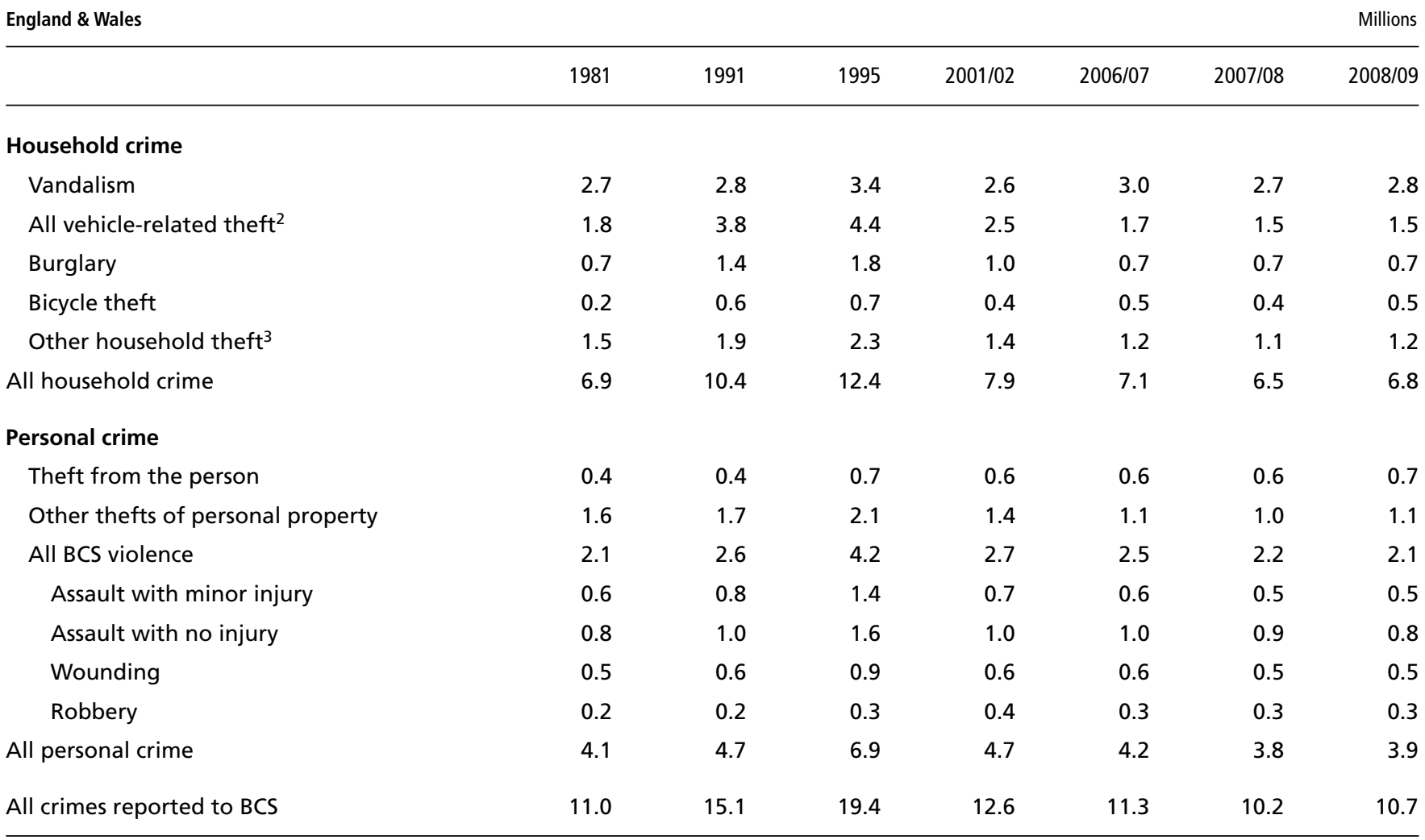

1 Until 2000 respondents were asked to recall their experience of crime in the previous calendar year. From 2001/02 onwards the British Crime Survey (BCS) became a continuous survey and the recall period was changed to the 12 months prior to interview.

2 Includes theft of, or from, a vehicle, as well as attempts.

3 Includes thefts and attempted thefts from domestic garages, outhouses and sheds, not directly linked to the dwelling, as well as thefts from both inside and outside a dwelling.

Source: British Crime Survey, Home Office

the 12 months prior to interview had been victims of this offence more than once during the period (Figure 9.4). Victims of domestic violence were most likely to report being a repeat victim, with 38 per cent of domestic violence victims experiencing this crime more than once in the 12 months prior to interview, and around a fifth (21 per cent) were victimised at least three times. The second most common offence reported by the same victim on more than one occasion within the last 12 months was vandalism (28 per cent).

In England and Wales there were 2.1 million violent offences reported in the BCS in 2008/09, a fall of 614,000 incidents since 2001/02. Assault without injury accounted for the largest proportion of violent offences (40 per cent) followed by assault with minor injury (25 per cent), wounding (22 per cent) and robbery (13 per cent). These proportions were very similar to those in 2007/08. The number of violent crimes increased during the 1980s to reach a peak of more than 4 million incidents by 1995. Incidents of BCS violent crime have fallen markedly since the mid-1990s to a level similar to 1981 (2.1 million crimes).
The risk of becoming a victim of violent crime varies according to personal characteristics. Except in cases of domestic violence, men are most likely to be victims of violent crime. In England and Wales in 2008/09, the overall risk of an adult becoming a victim of violent crime at least once in the 12 months prior to interview was 3.2 per cent (Figure 9.5). This proportion rose to 13.2 per cent for men aged 16 to 24 , compared with 5.5 per cent of women of the same age. The risk to a single person of becoming a victim of violence (7.6 per cent) was more than five times higher than the risk to a married person (1.4 per cent) and around twice as high as the risk to a cohabiting person (3.8 per cent) or a divorced person (3.2 per cent). The level of risk is also related to lifestyle. For example, those who visited a nightclub on average at least once a week were considerably more at risk (12.4 per cent) than those who had not visited a nightclub in the last month (2.5 per cent).

Firearms are defined as having been used in an incident if they are fired, used as a blunt instrument against a person, or used as a threat. The number of reported crimes in England and Wales involving the use of a firearm was 14,250 in 2008/09, 


\section{Figure 9.4}

\section{Repeat victimisation: ${ }^{1}$ by type of offence, 2008/09 \\ England \& Wales}

Percentages

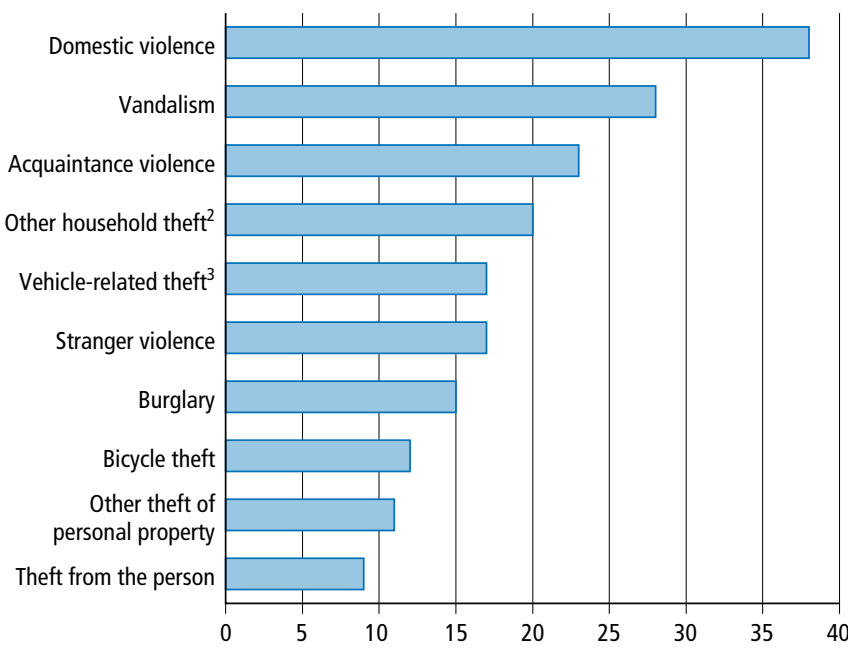

1 Victims of the same offence, or group of offences, more than once in the last 12 months.

2 Includes thefts and attempted thefts from domestic garages, outhouses and sheds, not directly linked to the dwelling, as well as thefts from both inside and outside a dwelling.

3 Includes theft of, or from, a vehicle, as well as attempts.

Source: British Crime Survey, Home Office

a decrease of 18 per cent from the previous year, 2007/08, when 17,343 offences were recorded, and a fall of 41 per cent since the peak of 24,094 offences recorded in 2003/04

(Figure 9.6). In 2008/09, 8,208 offences were committed in which firearms were reported to have been used (excluding air weapons) of which 2,671 were fired with 39 offences resulting

\section{Figure 9.5}

\section{Adults most at risk of violence, ${ }^{1}{ }_{2008 / 09}$}

England \& Wales

Percentages

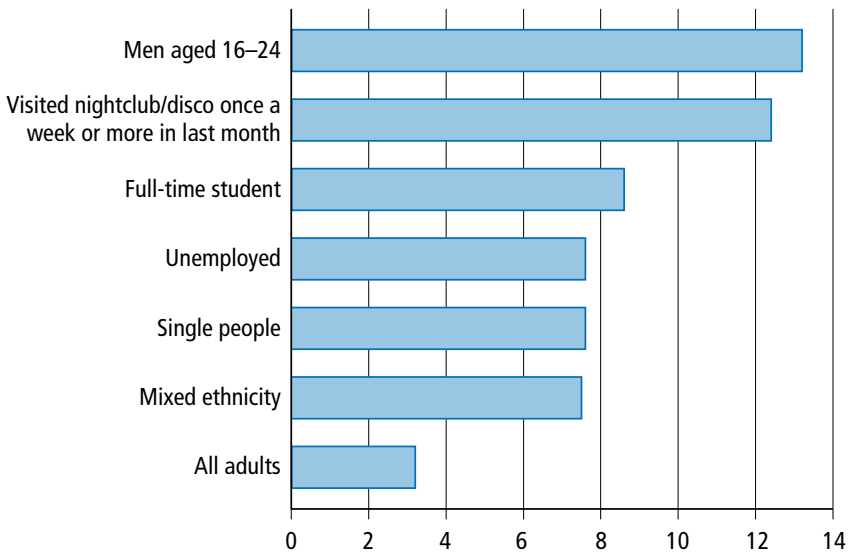

1 People who reported being a victim of violence one or more times in the 12 months prior to interview.

Source: British Crime Survey, Home Office

\section{Figure 9.6}

\section{Crimes ${ }^{1}$ reported to the police in which a firearm} had been used

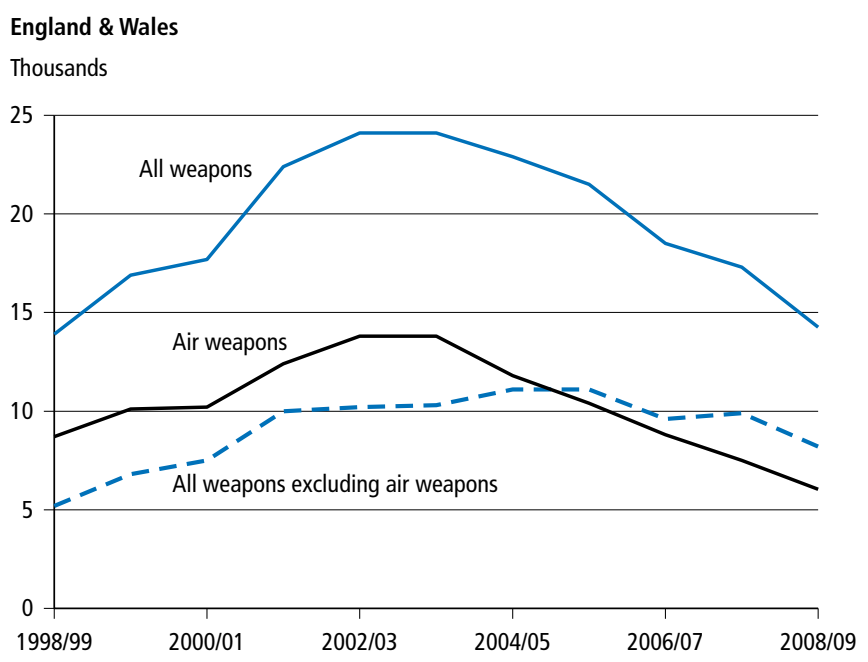

1 Changes in counting offences were made in April 1998 and the National Crime Recording Standard was implemented in April 2002. See Appendix, Part 9: National Crime Recording Standard.

Source: Home Office

in a fatal injury. During the same period, of the total number of firearm offences (excluding air weapons) committed, 5,337 offences were reported in which the weapon was not fired but was used as a blunt instrument or to threaten a person. The number of firearm offences (excluding air weapons) involving any kind of injury almost halved between 2007/08 and 2008/09, falling from 3,241 to 1,764.

An air weapon differs from the conventional firearm by the fact that it, and the pellets discharged, do not contain any explosive substance and most are of such limited powers that they are not required to be licensed, except those classified as dangerous weapons by the Firearms Rules 1969. In 2008/09, the number of reported crimes in England and Wales involving the use of an air weapon was 6,042, of which 5,340 reported incidents involved the air weapon being fired and 702 incidents were reported in which the air weapon was not fired but was used as a blunt instrument or to threaten a person.

Around half of firearm offences in 2008/09 (excluding those involving air weapons) involved a handgun (52 per cent). Imitation firearms were used in 18 per cent of incidents, shotguns in 8 per cent, and rifles in 1 per cent. Other firearms including CS gas, stun guns, and paintball guns accounted for 9 per cent of all firearm offences. The firearm was unidentified in 12 per cent of offences.

Table 9.3 showed that there were 1.5 million vehicle-related thefts against the household population in England and Wales in $2008 / 09$. Of these, 70 per cent of offences were thefts from 


\section{Figure 9.7}

\section{Vehicle-related theft ${ }^{1}$ \\ England \& Wales \\ Incidents}

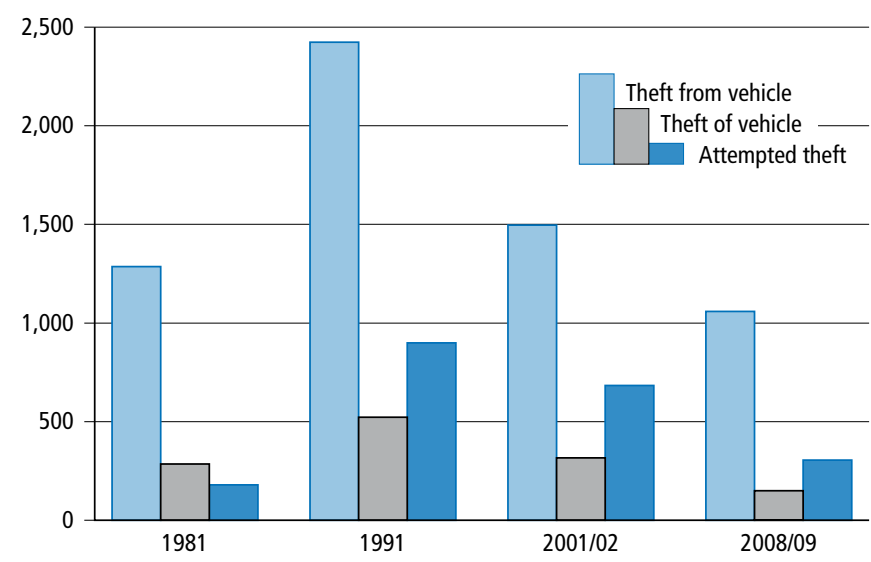

1 Until 2000 respondents were asked to recall their experience of crime in the previous calendar year. From 2001/02 onwards the British Crime Survey became a continuous survey and the recall period was changed to the 12 months prior to interview.

Source: British Crime Survey, Home Office

vehicles and 10 per cent were thefts of vehicles, while 20 per cent were attempted thefts either from or of the vehicle (Figure 9.7). In a pattern similar to violent crime, the number of offences in each of the vehicle-related theft categories had fallen by around two-thirds since they peaked in 1995 (see Table 9.3).

The fall in vehicle-related crime may be at least in part the result of better vehicle security. The proportion of vehicles in England and Wales fitted with security devices has risen over time and in 2008/09 the majority of vehicles had some form of security device installed: 91 per cent of main cars (that is, the car most used by the household) had central locking, and

The risk of being a victim of vehicle-related theft varies according to the employment status of the household reference person (see Reference persons text box on page 15). For example, in England and Wales in 2008/09, 10.1 per cent of households headed by a student had experienced vehicle-related theft, compared with 2.5 per cent of households headed by a retired person. The household's accommodation was also a risk factor: households living in flats or maisonettes were more likely to be victims of vehicle-related theft (8.3 per cent) than those living in detached houses (4.7 per cent). The risk to households with three or more cars (11.1 per cent) was more than double the risk to households with only one car (5.1 per cent).

In 2008, the value of transactions resulting from fraudulent use of UK credit and debit cards, both in the UK and overseas,

\section{Figure 9.8}

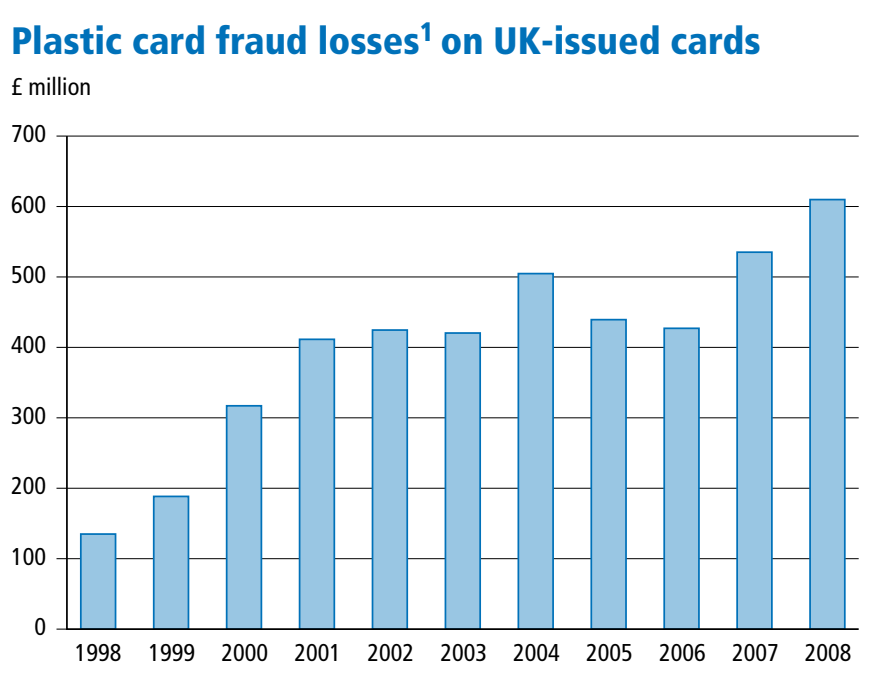

1 Value of transactions resulting from fraudulent use of UK credit and debit cards, both in the UK and overseas.

Source: The UK Cards Association

totalled $f 609.9$ million, an increase of 14 per cent on the previous year and over 350 per cent since 1998 (Figure 9.8). However, this amounted to 0.1 per cent of the total value of transactions made in 2008 using plastic cards issued in the UK. Losses of $£ 379.7$ million (62 per cent) occurred in the UK, compared with $\mathrm{f} 230.1$ million (38 per cent) of fraud which occurred abroad. More than half (54 per cent) of all losses on UK issued cards were through card-not-present transactions, and more than a quarter (28 per cent) resulted from the use of counterfeit cards. The remaining losses were a result of lost or stolen cards ( 9 per cent), card identity theft (8 per cent) and mail non-receipt, in which cards are stolen while in transit from the issuer to the cardholder (2 per cent).

Card-not-present fraud, where genuine card details are used to make a purchase online, over the phone or by post, increased by 350 per cent between 2000 (72.9 million frauds) and 2008 (328.4 million frauds). However, over the same period, the value of online shopping alone increased more than tenfold, from $\mathrm{f3} .5$ billion in 2000 to $\mathrm{f} 41.2$ billion in 2008 .

Counterfeit card fraud involves the unauthorised use of card details taken from the magnetic strip of a genuine card. Although the value of this type of card fraud taking place in UK increased by 9 per cent between 2007 and 2008, it fell by 68 per cent between 2004 and 2008 because of the introduction of chip and PIN, which requires people to enter a unique code, rather than signing their name, when purchasing goods. Counterfeit card fraud accounted for 58 per cent of losses in value that occurred abroad involving UK issued cards, as fraudsters use the cards in countries that do not yet have chip and PIN. 


\section{Perceptions of crime}

Table 9.2 showed that there were an estimated 10.7 million crimes committed in England and Wales in 2008/09, a fall of 45 per cent since the peak of 19.4 million crimes recorded in 1995. However, when asked if they believed crime levels had changed nationally and locally over the last two years, the 2008/09 British Crime Survey (BCS) reported that 75 per cent of respondents thought that crime levels across the whole country had increased over the last two years, but around half this proportion (36 per cent) thought that there was more crime in their local area.

This pattern of belief that crime had increased to a much greater extent nationally than in their local area was reflected in perceptions of the levels of individual types of crime. Almost four-fifths (78 per cent) of people living in private households in England and Wales in 2008/09 believed that knife crime had increased a lot nationally over the last two years, while 16 per cent thought it had increased a little (Table 9.9). At a local level, 8 per cent of people believed that knife crime had increased a lot and 21 per cent thought that it had increased a little. In contrast, BCS data show that knives were used in less than 8 per cent of all violent crimes in each year since 1995 (7 per cent in 2008/09).

Bank and credit card fraud were perceived to have gone up at a local level more than any other crime, with 22 per cent of people questioned stating that they thought bank and credit card fraud had gone up a lot in their area and 31 per cent thinking that it had gone up a little.

\section{Table 9.9}

\section{Perceptions of changing crime levels: by type of crime, ${ }^{1}$ 2008/09}

\begin{tabular}{|c|c|c|c|c|}
\hline \multirow[t]{3}{*}{ England \& Wales } & \multicolumn{4}{|r|}{ Percentages } \\
\hline & \multicolumn{2}{|c|}{ National level } & \multicolumn{2}{|c|}{ Local level } \\
\hline & $\begin{array}{r}\text { Increased } \\
\text { a lot }\end{array}$ & $\begin{array}{c}\text { Increased } \\
\text { a little }\end{array}$ & $\begin{array}{r}\text { Increased } \\
\text { a lot }\end{array}$ & $\begin{array}{r}\text { Increased } \\
\text { a little }\end{array}$ \\
\hline Knife crime & 78 & 16 & 8 & 21 \\
\hline Bank/credit card fraud & 70 & 21 & 22 & 31 \\
\hline Gun crime & 62 & 25 & 4 & 12 \\
\hline People getting beaten up & 55 & 29 & 9 & 25 \\
\hline Muggings/street robberies & 45 & 34 & 7 & 23 \\
\hline Vandalism & 40 & 33 & 9 & 28 \\
\hline Homes being broken into & 31 & 34 & 9 & 25 \\
\hline Cars being broken into & 34 & 30 & 9 & 23 \\
\hline Cars being stolen & 31 & 31 & 6 & 20 \\
\hline
\end{tabular}

1 British Crime Survey respondents were asked if they thought specific crimes had increased locally or nationally. Data are the proportion of people who answered 'increased a lot' or 'increased a little'.

Source: British Crime Survey, Home Office

The Crime and Disorder Act (1998) defined anti-social behaviour as 'acting in a manner that caused or was likely to cause harassment, alarm or distress, to one or more persons not of the same household (as the defendant)'. In 2008/09, 17 per cent of people questioned in England and Wales believed that there were high levels of anti-social behaviour in their area (Table 9.10). The most common anti-social behaviours

Table 9.10

Anti-social behaviour indicators ${ }^{1,2,3}$

England \& Wales

Percentages

\begin{tabular}{|c|c|c|c|c|c|c|c|}
\hline & 1992 & 1996 & 2000 & $2002 / 03$ & $2004 / 05$ & $2006 / 07$ & $2008 / 09$ \\
\hline Teenagers hanging around on the streets & 20 & 24 & 32 & 33 & 31 & 33 & 30 \\
\hline Rubbish or litter lying around & 30 & 26 & 30 & 33 & 30 & 31 & 30 \\
\hline People using or dealing drugs & 14 & 21 & 33 & 32 & 26 & 28 & 28 \\
\hline Vandalism, graffiti and other deliberate damage to property & 26 & 24 & 32 & 35 & 28 & 28 & 27 \\
\hline People being drunk or rowdy in public places & $\cdot$ & . & . & 23 & 22 & 26 & 26 \\
\hline Noisy neighbours or loud parties & 8 & 8 & 9 & 10 & 9 & 11 & 10 \\
\hline Abandoned or burnt-out cars ${ }^{4}$ & . & . & 14 & 25 & 12 & 9 & 6 \\
\hline High level of perceived anti-social behaviour ${ }^{5}$ & . & . & . & 21 & 17 & 18 & 17 \\
\hline
\end{tabular}

1 Until 2000 respondents were asked to recall their experience of crime in the previous calendar year. From 2001/02 the British Crime Survey became a continuous survey and the recall period was changed to the 12 months prior to interview.

2 People saying anti-social behaviour is a 'very/fairly big problem' in their area.

3 Percentages do not sum to 100 per cent as respondents could give more than one answer.

4 Question only asked of a quarter of the sample in 2002/03.

5 This measure is derived from responses to seven individual anti-social behaviour strands. See Appendix, Part 9: Anti-social behaviour indicators.

Source: British Crime Survey, Home Office 
identified were teenagers hanging around on the streets and rubbish or litter lying around, both reported by 30 per cent of survey respondents, followed by people using or dealing drugs (28 per cent); vandalism, graffiti and other deliberate damage to property (27 per cent); and people being drunk or rowdy in public (26 per cent). Between 2002/03 and 2008/09, the proportion of people who perceived abandoned or burned out cars to be a problem fell from 25 per cent to 6 per cent.

Perceived levels of anti-social behaviour varied according to household and area characteristics, age and sex. For example, 19 per cent of households in urban areas felt there to be a high level of anti-social behaviour in their area compared with 8 per cent of households in rural areas. People in social rented accommodation perceived higher levels of anti-social behaviour (29 per cent) than private renters (18 per cent) or owneroccupiers (13 per cent). Older people aged 65 and over (13 per cent) were less likely to feel that there was a high level of anti-social behaviour in their area compared to young people aged 16 to 24 (24 per cent). Young women were the most likely to feel that there was a high level of anti-social behaviour in their area: 29 per cent of women aged 16 to 24 compared with 20 per cent of men in the same age group. The gap between the sexes narrowed in the older age groups and at the oldest ages there was no difference: 9 per cent of both men and women aged 65 to 74 and 4 per cent of both men and women aged 75 and over felt there was a high level of anti-social behaviour problems in their area.

\section{Offenders}

Recorded crime figures based on administrative data collected by the police show that in 2008, 1.69 million offenders were found guilty of, or cautioned for, indictable and summary (including motoring) offences in England and Wales. (See Appendix, Part 9: Types of offence in England and Wales). Most of the offenders were male (76 per cent), of whom around 11 per cent were aged under 18 .

In 2008, 32,700 people aged 10 to 14 were found guilty of, or cautioned for, an indictable offence in England and Wales. Males in this age group were more likely than females to be offenders, 22,200 compared with 10,500 (Figure 9.11). Of all offenders who were found guilty of, or cautioned for, an indictable offence in 2008, 35 per cent were aged 20 to 29, the highest proportion for any age group. The proportion of the population who were offenders declined with age as males and females entered their 30s. Less than 15 per cent of males and females over the age of 40 were found guilty of, or cautioned for, an indictable offence in 2008. For those aged 60 and over the proportion of the population who were offenders was negligible.

\section{Figure 9.11}

\author{
Offenders: $1,2,3$ by age \\ England \& Wales \\ Thousands
}

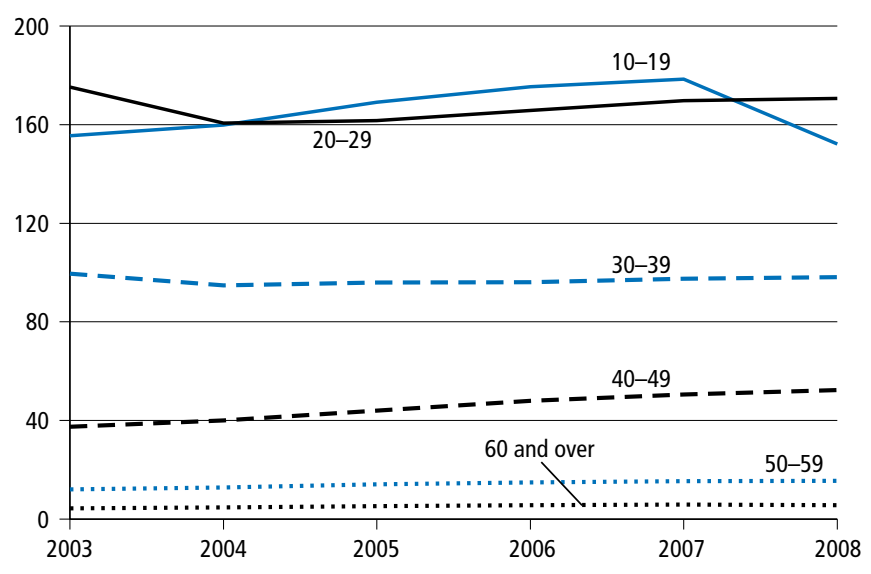

1 People found guilty of, or cautioned for, indictable offences.

2 For motoring offences only persons found guilty are included; these offences may attract written warnings, which are not included in this chart.

3 Data for April, July and August 2008 excludes convictions data for Cardiff magistrates' court.

Source: Office for Criminal Justice Reform, Ministry of Justice

In Northern Ireland, 7,600 offenders were found guilty of, or cautioned for, indictable offences in 2006. Of these, 88 per cent were male. Young men aged 19 and 20 were most likely to be offenders, with 4 per cent of this age group being found guilty of, or cautioned for, an indictable offence. The proportion of women who were offenders was less than 1 per cent for all age groups.

The type of indictable offences for which people were found guilty of, or cautioned for, were similar for men and women in England and Wales in 2008. For both men and women, the most common indictable offence was theft and handling stolen goods accounting for 31 per cent of all male offences $(125,200)$ and 52 per cent of all female offences $(48,900)$ (Figure 9.12). The second most common offences for men were drug offences $(88,800)$ at 22 per cent followed by violence against the person $(65,100)$ at 16 per cent of all male offences. Theft and handling stolen goods, violence against the person and drug offences accounted for the majority of all offences by females (78 per cent). 'Other offences', which include fraud and forgery and indictable motoring offences, accounted for 16 per cent of offences for both men and women.

In Northern Ireland, the most common offences to be found guilty of, or cautioned for, in 2006 were violent offences (violence against a person, sexual offences, and robbery) and acquisitive offences (theft, burglary and fraud and forgery) 


\section{Figure 9.12}

\section{Offenders found guilty of, or cautioned for, indictable offences: ${ }^{1}$ by sex and type of offence, 2008}

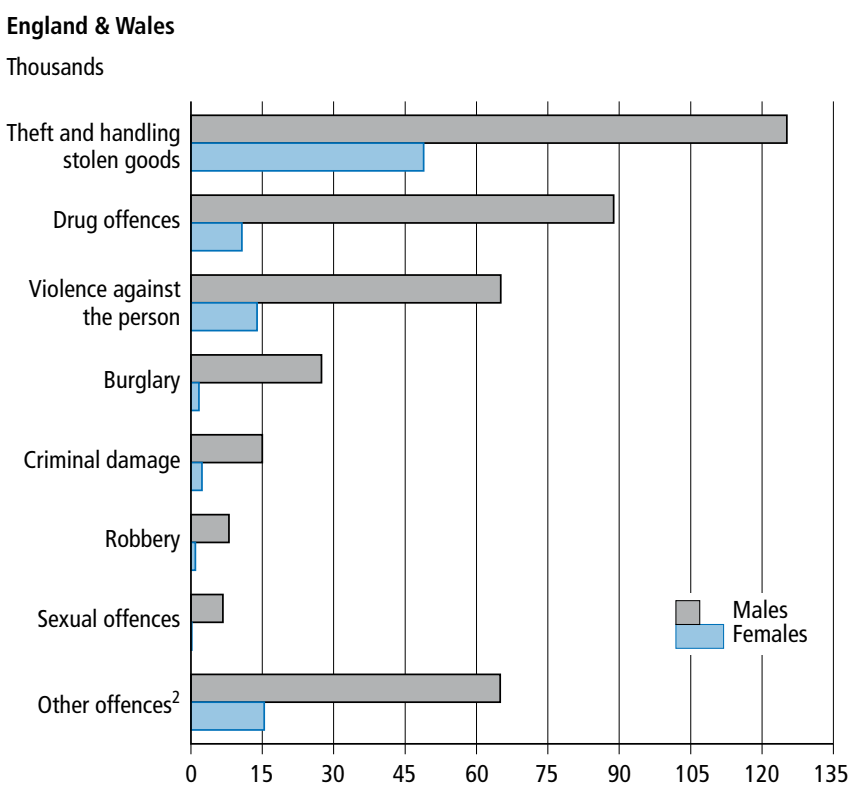

1 See Appendix, Part 9: Types of offence in England and Wales. 2 Includes fraud and forgery and indictable motoring offences.

Source: Office for Criminal Justice Reform, Ministry of Justice both at 34 per cent, followed by criminal damage and drug related offences, at 17 per cent and 10 per cent respectively.

Not all offences have to be dealt with by the court, the police can deal with some people using a range of alternatives such as a simple caution, conditional caution, penalty notice for disorder or fixed penalty notice for motoring offences. Once the police obtain enough evidence for conviction, the offenders are charged and taken to court where, if found guilty, the court imposes a sentence. Sentences in England, Wales and Northern Ireland can include immediate custody, a community sentence, a fine or, if the court considers that no punishment is necessary, a discharge. In 2008, of the 495,200 offenders found guilty of, or cautioned for, indictable offences in England and Wales, 63 per cent (310,000 offenders) were sentenced (Table 9.13). The type of sentence given depends on the offence committed and other factors that may be applied on a case-by-case basis (see Appendix, Part 9: Sentences and orders). In 2008, the most common type of sentence was a community sentence (32 per cent), with more than two-fifths (44 per cent) of offenders sentenced for criminal damage receiving this sentence. Suspended sentence order was the least common sentence given at 9 per cent, with violence against a person and motoring offenders being the most likely offenders (18 per cent) to receive this sentence.

Table 9.13

Offenders sentenced for indictable offences: by type of offence ${ }^{1}$ and type of sentence, ${ }^{2} 2008$

\begin{tabular}{|c|c|c|c|c|c|c|c|}
\hline & Discharge & Fine & $\begin{array}{r}\text { Community } \\
\text { sentence }\end{array}$ & $\begin{array}{r}\text { Suspended } \\
\text { sentence } \\
\text { order }\end{array}$ & $\begin{array}{l}\text { Immediate } \\
\text { custody }\end{array}$ & Other & $\begin{array}{r}\text { All sentenced } \\
(=100 \%) \\
\text { (thousands) }\end{array}$ \\
\hline Theft and handling stolen goods & 20 & 13 & 37 & 6 & 19 & 6 & 109.5 \\
\hline Drug offences & 16 & 33 & 23 & 6 & 18 & 4 & 52.4 \\
\hline Violence against the person & 5 & 4 & 36 & 18 & 33 & 4 & 39.8 \\
\hline Burglary & 3 & 2 & 40 & 10 & 42 & 4 & 23.6 \\
\hline Fraud and forgery & 14 & 12 & 28 & 15 & 30 & 3 & 16.9 \\
\hline Criminal damage & 21 & 11 & 44 & 5 & 12 & 8 & 9.4 \\
\hline Motoring & 3 & 20 & 27 & 18 & 30 & 2 & 4.6 \\
\hline Robbery & 0 & 0 & 34 & 5 & 60 & 2 & 8.5 \\
\hline Sexual offences & 3 & 2 & 27 & 8 & 58 & 2 & 5.1 \\
\hline Other offences & 9 & 28 & 23 & 10 & 24 & 7 & 40.3 \\
\hline All indictable offences & 13 & 16 & 32 & 9 & 25 & 5 & 310.0 \\
\hline
\end{tabular}

1 See Appendix, Part 9: Types of offence in England and Wales.

2 Data are based on the principle offence basis, where an offender has been sentenced for more than one offence the principle offence is the one for which the heaviest sentence was imposed. See Appendix, Part 9: Sentences and orders.

Source: Ministry of Justice 


\section{Prisons and sentencing}

Prison is the usual eventual destination for offenders given custodial sentences, and also for those who break the terms of their non-custodial sentence. Sentenced prisoners are classified into different risk-level groups for security purposes. Women prisoners are held in separate prisons or in separate accommodation in mixed prisons. Young offenders receiving custodial sentences have traditionally been separated from adult offenders, enabling them to receive additional educational and rehabilitative treatment.

The size of the prison population in England and Wales (those held in prison but excluding those in police cells, see Appendix, Part 9: Prison population for more details) has risen by 79 per cent over the years from 17,435 in 1900 when the records began to reach 82,572 in 2008 . During this period the population of females in prisons almost doubled from 2,976 in 1900 to 4,414 in 2008, but decreased as a proportion of the male population from 17 per cent in 1900 to 5 per cent in 2008 (Figure 9.14). The prison population was relatively stable during the 1970s and early 1990s, but in the mid-1990s it began to increase. The largest increase during the 1990s occurred between 1996 and 1997 at 11 per cent. Apart from decreases of less than 1 per cent in 1993 and again in 1999, the prison population has increased annually since 1991.

Of the 70,800 British nationals in prison in England and Wales in 2008, the majority were White (79 per cent of male inmates and 83 per cent of female inmates) (Table 9.15). The second largest ethnic group within the prison population in 2008 was

\section{Figure 9.14}

\section{Average prison population: ${ }^{1,2}$ by sex}

\section{England \& Wales}

Thousands

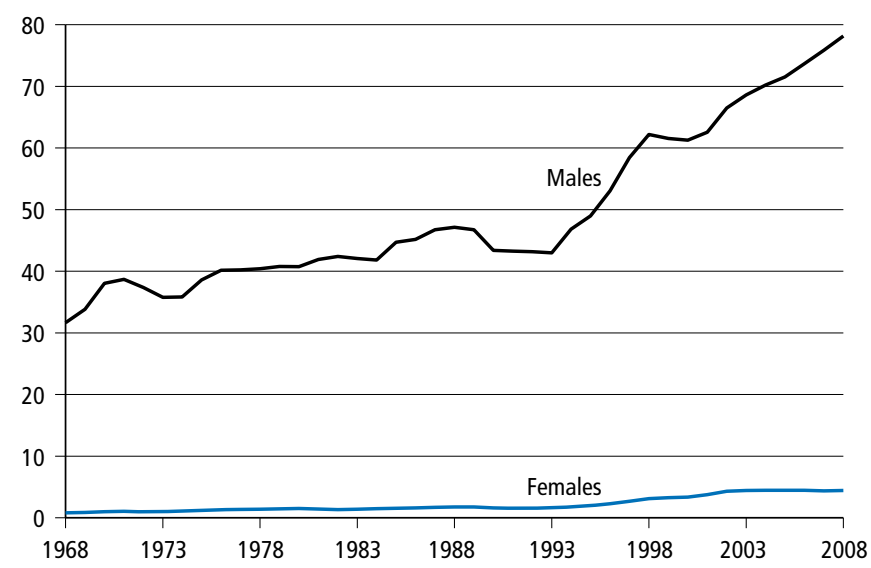

1 Data are annual averages

2 Excludes prisoners held in police cells.

Source: Ministry of Justice
Table 9.15

\section{Prison population of British nationals: by ethnic group $^{1}$}

England \& Wales

Percentages

$\begin{array}{lllll}2004 & 2005 \quad 2006 \quad 2007 \quad 2008\end{array}$

\section{Males}

White

Mixed

Asian or Asian British

Black or Black British

Chinese and other ethnic group

Total male population

(=100\%) (thousands)

$\begin{array}{lllll}60.8 & 62.1 & 62.7 & 64.5 & 67.3\end{array}$

\section{Females}

White

Mixed

Asian or Asian British

Black or Black British

Chinese and other ethnic group

Total female population

$(=100 \%)$ (thousands)

$\begin{array}{rrrrr}75 & 82 & 81 & 80 & 79 \\ 2 & 3 & 3 & 3 & 3 \\ 4 & 5 & 5 & 5 & 5 \\ 9 & 10 & 11 & 11 & 11\end{array}$

1 See Appendix, Part 1: Classification of ethnic groups.

Source: Ministry of Justice

Black or Black British, at 11 per cent of male inmates and 9 per cent of female inmates. The proportions of male and female inmates who were from the Mixed ethnic group were similar ( 3 per cent and 4 per cent respectively) but there were more Asian or Asian British males in prison ( 5 per cent of all inmates) than Asian or Asian British females (2 per cent).

On 30 June 2009 the prison population was 83,454, with a further 258 people held in secure training centres and 175 in local authority children's homes, an increase in total prison population of less than 1 per cent compared with June 2008. The increased prison population may partly result from a rise in the use of longer prison sentences. Average custodial sentence lengths given by the Crown court have increased from 21.8 months in 1998 to 24.5 months in 2008. Over the same period, the average length of custodial sentences given by the magistrates' courts has been stable at around three months.

In 2007, there were 2.7 million motoring offences in England and Wales dealt with by official police action or penalty notice charge, of which 2.6 million were fixed penalty notices issued by the police (including traffic wardens) which were paid and thus resulted in no further action. Speed and traffic light cameras in England and Wales provided evidence for almost 
Table 9.16

\section{Fixed penalties ${ }^{1}$ for motoring offences detected by cameras: by type of offence}

\begin{tabular}{lrrr} 
England \& Wales & $\begin{array}{r}\text { Speeding } \\
\text { offences }\end{array}$ & $\begin{array}{r}\text { Traffic light } \\
\text { offences }\end{array}$ & $\begin{array}{r}\text { All } \\
\text { offences }\end{array}$ \\
\hline 2001 & 878 & 46 & 923 \\
2002 & 1,135 & 71 & 1,206 \\
2003 & 1,670 & 115 & 1,785 \\
2004 & 1,787 & 113 & 1,900 \\
2005 & 1,764 & 123 & 1,887 \\
2006 & 1,634 & 119 & 1,752 \\
2007 & 1,260 & 109 & 1,369 \\
\hline
\end{tabular}

1 Includes paid, fixed penalties only. Offences where the fixed penalty was not paid are not counted, as further action was taken.

Source: Home Office

1.4 million of these fixed penalties, an increase of nearly half (48 per cent) compared with 2001 (Table 9.16). The majority (92 per cent) of those offences for which evidence had been provided by a camera were speeding offences, with the remainder being traffic light offences. Overall, cameras were used to provide evidence for 86 per cent of speeding offences in 2007 that resulted in fixed penalty notices being issued. Cameras were also used in 53 per cent of offences of neglect of traffic signs and directions and pedestrian rights, which includes traffic light offences.

Fixed penalty notices are motoring offences that are issued on the spot, and can be endorsable (accompanied by points added on the driving licence) or non-endorsable (no points added).

There was a fall in the number of fixed penalty notices issued in England and Wales for the use of a hand-held mobile phone while driving, from 167,000 offences in 2006 to 122,000 offences in 2007. This is partly because, at the end of February 2007, the offence was changed from a non-endorsable offence to an endorsable offence, increasing the penalty and adding points to the offender's licence.

In 2007, 90 per cent of fixed penalty notices issued by the police were paid. Fixed penalty notices issued for endorsable offences were more likely to be paid without further enforcement action than were those for non-endorsable offences: 98 per cent of fixed penalty notices issued for endorsable offences were paid compared with 74 per cent of non-endorsable offences where the driver was present and 73 per cent of non-endorsable offences where the driver was not present.

Anti-social behaviour orders (ASBOs) were introduced in England and Wales under the Crime and Disorder Act (1998)
Figure 9.17

\section{Number of anti-social behaviour orders (ASBOs) issued: ${ }^{1}$ by age}

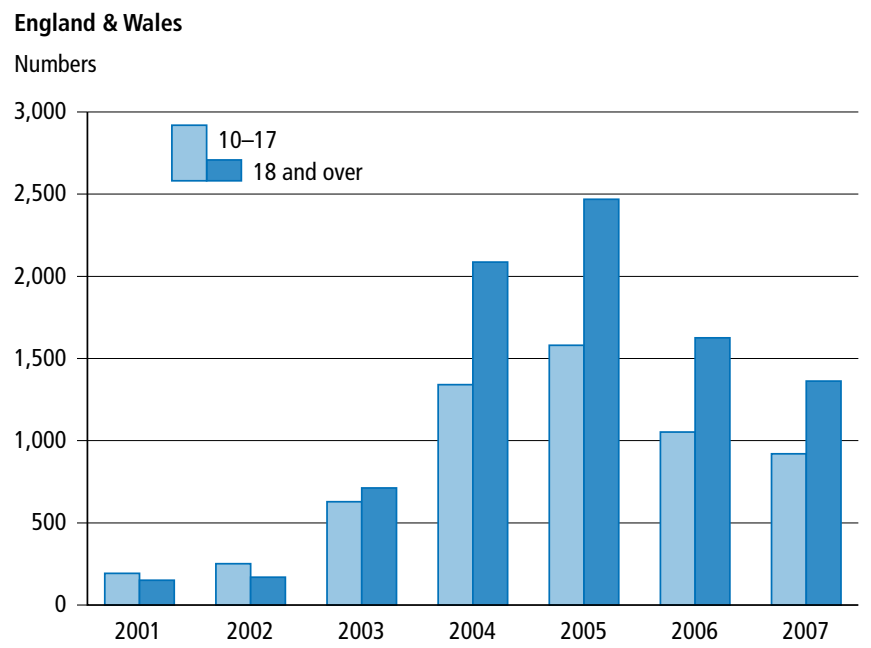

1 Issued at all HM Courts and reported to the Home Office by the Courts Service.

Source: Home Office

and have been available since April 1999. ASBOs are civil orders that impose restrictions on the behaviour of individuals who have behaved in an anti-social way in order to protect communities from often longstanding and intimidating activity. They can be made against anyone aged 10 and over.

The number of ASBOs issued in England and Wales increased from 350 in 2001 to a peak of 4,122 in 2005, since when they have fallen back to 2,299 in 2007. The increase between 2003 and 2005 followed the introduction of the Anti-Social Behaviour Act in 2003. This Act strengthened the ASBO by increasing the number of categories for which ASBOs can be awarded, enhancing their legal status and banning spray paint sales to people under the age of 16 , and also gave local councils the power to order the removal of graffiti from private property. It also covers truancy, people making false reports of emergency, misuse of fireworks, private drunkenness and gang activity.

Of the 2,299 ASBOs issued in 2007, 17 ASBOs were to persons of unknown age. Of the 2,282 ASBOs issued to persons of known age 1,362 were issued to individuals aged 18 and over, and 920 were issued to 10 to 17 -year-olds (Figure 9.17). A larger proportion of males than females were issued ASBOs in 2007. Of the total number of ASBOs issued in this year, half (50 per cent) were issued to men aged 18 and over and more than a third (36 per cent) were issued to males aged 10 to 17 , while 9 per cent were issued to women aged 18 and over and 4 per cent were issued to females aged 10 to 17 . The remaining 1 per cent were issued to males whose age was unknown. 
Table 9.18

\section{People sentenced to life imprisonment: ${ }^{1}$ by sex}

\begin{tabular}{lccc} 
England \& Wales & & & Numbers \\
\hline & Males & Females & $\begin{array}{r}\text { All } \\
\text { people }\end{array}$ \\
\hline 1998 & 380 & 14 & 394 \\
2000 & 446 & 21 & 467 \\
2002 & 536 & 19 & 555 \\
2004 & 548 & 22 & 570 \\
2006 & 531 & 16 & 547 \\
2008 & 495 & 28 & 523 \\
\hline
\end{tabular}

1 See Appendix, Part 9: Sentences and orders.

Source: Ministry of Justice

Between June 2000 and December 2007 a total of 14,972 ASBOs were issued in England and Wales. Of these, more than half (53 per cent) were proved in court to have been breached at least once and 39 per cent were proved to have been breached more than once.

Life imprisonment, or its equivalent, must be imposed on all persons aged 10 and over convicted of murder. This sentence may also be imposed for a number of the most serious crimes, including manslaughter, robbery, rape, assault with intent to do grievous bodily harm, aggravated burglary, and certain firearms offences. In 2008, 523 people were sentenced to life imprisonment in England and Wales, a fall of 4 per cent compared with 2006 (Table 9.18). The great majority of people sentenced to life imprisonment were men (95 per cent) and just over one in ten (11 per cent) were aged 18 to 20 and one in twenty (almost 5 per cent) were males aged 10 to 17.

In Scotland, 32 people were sentenced to life imprisonment in 2008, excluding those given indeterminate sentences. This was a decrease of 21 persons on the previous year. More than three-quarters (78 per cent) were men aged 21 and over, and 19 per cent were men aged 18 to 20 . No life sentences have been issued to anyone aged under 18 in Scotland since 2004.

\section{Resources}

There were 43 police forces in England and Wales employing 143,770 full-time equivalent police officers at 31 March 2009, the highest number of police officers ever recorded. Of these, 6,290 police officers were from an ethnic minority group, equivalent to 4.4 per cent of the total police strength and double the proportion recorded in 2000 (2.2 per cent) (Table 9.19). The proportion of police officers belonging to an ethnic minority was lower at senior ranks. In 2009, 2.8 per cent

\section{Table 9.19}

\section{Ethnic ${ }^{1}$ minority police officers as a proportion of all police officers: by rank ${ }^{2}$}

\begin{tabular}{lcc} 
England \& Wales & \multicolumn{2}{c}{ Percentages } \\
\hline & 2008 & 2009 \\
\hline Association of Chief Police Officers & 3.3 & 4.0 \\
Chief Superintendents & 2.3 & 2.8 \\
Superintendents & 2.9 & 3.2 \\
Chief Inspectors & 3.0 & 2.7 \\
Inspectors & 2.6 & 3.1 \\
Sergeants & 3.0 & 3.2 \\
Constables & 4.4 & 4.8 \\
All ethnic minority police officers & 4.1 & 4.4 \\
\hline
\end{tabular}

1 See Appendix, Part 1: Classification of ethnic groups.

2 As at 31 March in each year.

Source: Home Office

of officers at chief superintendent level were from an ethnic minority compared with 4.8 per cent of officers who were constables. One per cent of officers did not state their ethnicity in 2009. Of the officers who stated they were from an ethnic minority group, 39.3 per cent were Asian or Asian British, 27.0 per cent were from the Mixed ethnic group, 22.7 per cent were Black or Black British and 11.0 per cent were from the Chinese or Other ethnic group.

The proportion of ethnic minority officers varies by police force in England and Wales. The largest proportion of ethnic minority officers were based in the Metropolitan Police force (8.8 per cent) which accounted for 45 per cent of all ethnic minority police officers in England and Wales, followed by West Midlands (7.7 per cent), accounting for 11 per cent, Leicestershire (6.6 per cent) accounting for 2 per cent and Bedfordshire (6.1 per cent) accounting for 1 per cent. Police officers from ethnic minority groups accounted for less than 1 per cent of the total police strength in four police force areas in 2009: North Wales (0.8 per cent), Devon and Cornwall (0.8 per cent), Dyfed Powys (0.7 per cent) and Humberside (0.9 per cent).

A quarter (25.1 per cent) of all police officers in England and Wales were women at 31 March 2009. This proportion was lower in the more senior ranks with 13.0 per cent of officers at rank of chief inspector or above being female compared with 27.9 per cent who were constables.

According to the 2008/09 British Crime Survey just over two-thirds (67 per cent) of people in England and Wales had overall confidence in the police in their local area, a 
Table 9.20

\section{Ratings and perceptions of local police}

England \& Wales

Percentages

\begin{tabular}{rrr}
\hline $2005 / 06 \quad 2006 / 07 \quad 2007 / 08 \quad 2008 / 09$
\end{tabular}

\section{Ratings of local police ${ }^{1}$}

How good a job do you think the police are doing

50

51

53

53

\section{Perceptions of police in local area ${ }^{2}$}

Would treat you with respect if you had contact with them

82

84

Treat everyone fairly regardless of who they are

63

60

Are dealing with the things that matter to people in the community

Can be relied on to be there when you need them

47

47

51

Can be relied on to deal with minor crimes

42

41

48

Overall confidence in the local police 2,3
64

1 Proportion of respondents who rated police as excellent/good.

2 Proportion of respondents who strongly agreed/tended to agree with the statement.

3 Based on the question 'Taking everything into account I have confidence in the police in this area'.

Source: British Crime Survey, Home Office

2 percentage point increase since 2007/08 (Table 9.20). More than half (53 per cent) of people thought that their local police force was doing a good or excellent job, the same proportion as the previous year, and a 3 percentage point increase since 2005/06. In general, these indicators showed that the majority of people in England and Wales agreed that their local police treat people with respect (84 per cent), that they treat everyone fairly (65 per cent), and that they understand the issues affecting the community (65 per cent). People were less likely to agree that their local police force could be relied upon to be there when needed (48 per cent) or to deal with minor crimes (46 per cent).

The proportion of people who agreed that their local police force was doing a good or excellent job in 2008/09 varied according to certain demographic characteristics. For example, women were more inclined than men to rate the police as doing a good or excellent job (56 per cent compared with 51 per cent) and people from non-White groups were more likely than White people to rate the police as doing a good or excellent job (57 per cent compared with 53 per cent). However, 67 per cent of men thought that the police would treat people fairly, compared with 63 per cent of women. Similarly, 84 per cent of White people thought that the police would treat people with respect, compared with 81 per cent of people from non-White groups.

In 2008/09, a total of 31,259 complaint cases were made by members of the public against those serving with the police in
England and Wales, an increase of 8 per cent on the previous year and the most complaints recorded in a single year since 1990 (Figure 9.21). Complaints were made by 31,673 individuals in England and Wales in 2008/09, a rate of approximately one complainant per complaint. Almost two-thirds (63 per cent) of complainants were White,

\section{Figure 9.21}

\section{Number of complaint cases recorded ${ }^{1,2}$ by police forces}

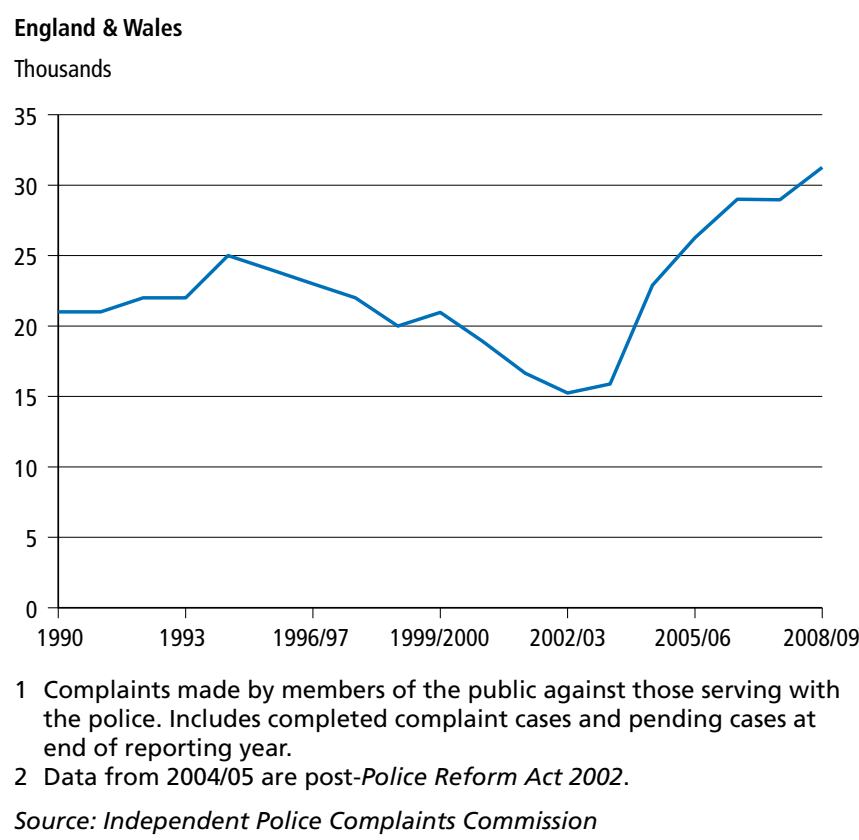


7 per cent were Black, 6 per cent were Asian, 3 per cent were in the Other ethnic group and the ethnicity of around a fifth (22 per cent) of complainants was unknown.

A complaint may comprise one or more allegations, for example, a person may complain that a police officer was rude to them (one complaint) or that he was rude to them and that he pushed them (two allegations but treated as one complaint). There were 53,534 allegations in England and Wales in 2008/09, a rise of 11 per cent on 2007/08. The most common types were 'incivility, impoliteness and intolerance' (21 per cent), which includes abusive, offensive or rude language or behaviour, and 'other assault' (13 per cent), which includes allegations that unreasonable force was used. Allegations of 'other neglect or failure in duty' (24 per cent) includes allegations such as a failure to record or investigate matters and keep interested parties informed. Allegations of discriminatory behaviour formed 3 per cent of the total, the majority of which (76 per cent) concerned allegations of racial discrimination.

The British Crime Survey asked people in England and Wales how confident they were that the Criminal Justice System (CJS) was fair and effective. Overall, 59 per cent of people questioned in 2008/09 thought that the CJS was fair although fewer people (38 per cent) thought that it was effective. However, levels of confidence in the CJS, particularly in its effectiveness, vary considerably by the respondent's occupation (Table 9.22). For example, 72 per cent of full-time students felt that the CJS was fair and 60 per cent thought that it was effective. In comparison, 56 per cent of those in intermediate or routine and manual occupations felt that the CJS was fair and 35 per cent of those in managerial and professional or intermediate occupations thought that it was effective.

\section{Table 9.22}

\section{Confidence in the criminal justice system (CJS): by respondent's occupation, 2008/09}

\begin{tabular}{lcr} 
England \& Wales & Percentages \\
\hline & $\begin{array}{r}\text { Confidence } \\
\text { that the } \\
\text { CJS is fair }\end{array}$ & $\begin{array}{r}\text { Confidence } \\
\text { that the } \\
\text { CJS is } \\
\text { effective }\end{array}$ \\
\hline Managerial and professional occupations & 59 & 35 \\
Intermediate occupations & 56 & 35 \\
Routine and manual occupations & 56 & 38 \\
Never worked and long-term unemployed & 68 & 52 \\
Full-time students & 72 & 60 \\
Not classified & 49 & 32 \\
\hline
\end{tabular}

Source: British Crime Survey, Home Office

White people were less likely to have confidence in the CJS than people from other ethnic groups. In 2008/09, 57 per cent of White people thought that the CJS was fair and 36 per cent thought that it was effective. In comparison, 72 per cent of Asian or Asian British people thought that the CJS was fair and 61 per cent thought that it was effective. For Black and Black British people, the equivalent figures were 60 per cent and 51 per cent.

People who had any type of contact with the police in the 12 months prior to interview were slightly less likely to believe that the CJS was fair (57 per cent) or effective (37 per cent) that those who had not had contact with the police (61 per cent and 40 per cent). 